\title{
Geotechnical and Geomechanical Characterisation of the Goathill North Rock Pile at the Questa Molybdenum Mine, New Mexico, USA
}

\author{
L.A.F. Gutierrez Golder Associates Inc., USA \\ V.C. Viterbo Phelps Dodge, USA \\ V.T. McLemore New Mexico Tech, Bureau of Geology and Mineral Resources, USA
}

C.T. Aimone-Martin New Mexico Tech, Department of Mineral Engineering, USA

\begin{abstract}
Physical changes due to weathering are of interest with respect to predicting long-term geotechnical slope stability of rock piles at the Questa molybdenum mine, New Mexico, USA. Geotechnical and geomechanical characterisation was conducted on matrix soil and rock fragments in the Goathill North (GHN) rock pile and on non-weathered drill core samples of rock typical of GHN. Shear strength and rock durability was estimated by performing direct shear, point load strength, and slake durability tests. Measurements for Atterberg Limits, particle size, moisture content, and density were also performed.

Samples had high peak internal friction angles ( $\phi$ ) between $42^{\circ}$ and $47^{\circ}$, which can in part be attributed to the grain shape (subangular to very angular). Point load strength index (Is50) and slake durability index $\left(I D_{2}\right)$ classified the samples as medium to very high strength and having high to extremely high durability, respectively. Lowest values of $\phi$, Is50, and $I D_{2}$ were observed for samples from the outer margin of the pile. $I D_{2}$ results suggest that samples from the interior of the pile have been weathered little since deposition. In general, GHN rock pile samples have high durability and strength even after having undergone hydrothermal alteration and blasting prior to deposition and after potential exposure to weathering for about 40 years. Collectively, these results suggest that future weathering will not substantially decrease the friction angle of the rock piles with time.
\end{abstract}

\section{Introduction}

Factors leading to the instability of rock piles include loss of material strength caused by weathering (Tesarik and McKibbin, 1999). Weathering is the process of rock and mineral alteration to more stable forms under the variable conditions of moisture, temperature, and biological activity that prevail at or near the surface (Birkeland, 1999). Two main types of weathering are recognised: physical weathering, in which the original rock disintegrates to smaller-sized material with no appreciable change in chemical or mineralogical composition, and chemical weathering, in which chemical and/or mineralogical composition of the original rock and minerals are changed (Clark and Samall, 1982). The mechanism common to all processes of physical weathering is the establishment of sufficient stress within the rock so that the rock breaks. Physical weathering results in a decrease in grain size, which increases surface area that in turn leads to greater chemical reactivity and the exposure of fresh mineral surfaces. Chemical weathering processes include dissolution, carbonation, hydration, hydrolysis, oxidation and reduction (Birkeland, 1999; Clark and Samall, 1982; Gerrard, 1988). Evidences of chemical weathering are shown by several field and laboratory criteria including: (1) change in colour due to oxidation of iron-bearing minerals, (2) depletion of original minerals (pyrite, calcite, clays), (3) increase in new weathered minerals (i.e. gypsum, jarosite), (4) changes in majorelement chemistry, and (5) the water chemistry of soils and streams in a particular basin (Birkeland, 1999).

The evolution of grain sizes can result in a change in the shear strength and permeability properties of the mine rock and alter the physical stability of the mine rock structures. The internal angle of friction for nonweathered rock pile materials at the time of placement is routinely greater than $41^{\circ}$, which exceeds the constructed slope angles of repose at $38^{\circ}$, thus producing stable slopes under static conditions (Wilson et al., 2005). Weathering of waste rock may decrease particle size, friction angle (strength) and rock durability. 
In 2002, Chevron Mining Inc. (formerly Molycorp Inc.), the owner of the Questa molybdenum mine, initiated an extensive study by an independent consortium of academicians and consultants to examine the effects of weathering on the present and future stability of the Goathill North (GHN) rock pile. As part of this investigation, geotechnical and geomechanical characterisation was conducted from 2004 through 2007. Slake durability, point load and direct shear tests were performed in order to evaluate the durability and strength of the rock pile material. Laboratory tests included direct shear, point load strength, and slake durability tests, Atterberg Limits, and particle size analyses. The purpose of this paper is to present the preliminary findings of the investigation on the effect of weathering on the geotechnical and geomechanical properties of the GHN rock pile material.

\section{Site description}

The Questa molybdenum mine is located near Taos in northern New Mexico, USA (Figure 1). The mine has had underground and open pit mining operations since 1918. During the open-pit period of mining, approximately 317.5 million metric tons of overburden rock was deposited in nine major rock piles. The Questa rock piles were constructed onto mountain slopes and into tributary valleys mostly by haul truck end dumping in high, single lifts, which involves the dumping of rock over the edge of the hill slopes (URS Corporation, 2000). End dumping generally results in the segregation of materials with the finer-grained material at the top and coarser-grained material at the base. In general, the rock piles are at the angle of repose $\left(35^{\circ}\right.$ to $\left.40^{\circ}\right)$ and have long slope lengths (up to $600 \mathrm{~m}$ ) and comparatively shallow depths $(\sim 30-60 \mathrm{~m})$ (Shaw et al., 2002).

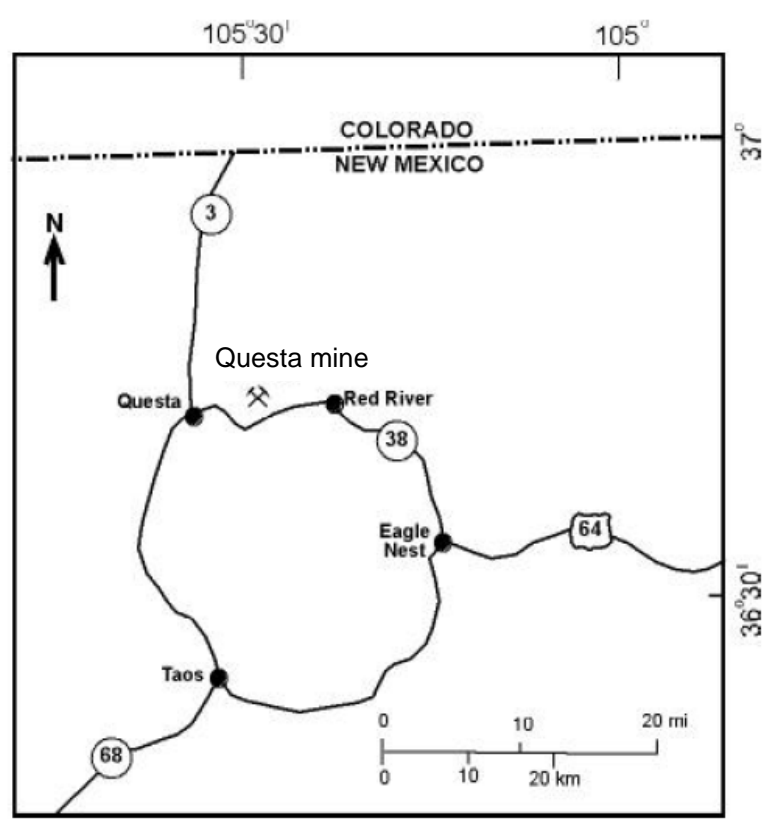

Figure 1 Location of Questa mine, northern Taos County, New Mexico
The Goathill North (GHN) rock pile was constructed between 1964 and 1974 with approximately 4.2 million $\mathrm{m}^{2}$ of material and has a maximum height of approximately $183 \mathrm{~m}$ (Norwest Corporation, 2004). Studies by Norwest Corporation (2003) revealed that the GHN rock pile was constructed in an area characterised by hydrothermal alteration scars. These hydrothermal alteration scars are natural, colourful (red to yellow to orange to brown), relatively unstable landforms that are characterised by steep slopes (greater than $25^{\circ}$ ), moderate to high pyrite content (typically greater than $1 \%$ ), little or no vegetation, and extensively fractured bedrock (McLemore et al., 2004; Meyer and Leonardson, 1990). The GHN rock pile is founded on sheared colluvium derived in part from the hydrothermal alteration scars. Failure of the foundation resulted in portions of GHN creeping, which first occurred between 1969 and 1973 (Norwest Corporation, 2003, 2004), and this creeping continued to occur for more than 30 years, until the initial remediation of that pile was completed in 2005. The remediation procedure consisted of regrading the slope to reduce the load on the foundation and form a buttress at the toe to prevent further movement of the material.

\section{Methodology}

\subsection{Sample collection}

The regrading of the top of GHN brought a unique opportunity to examine the undisturbed internal geology of the rock pile through the construction of trenches cut into the pile as earth moving progressed. Maps of 
each bench were compiled to document the different stratigraphic units, including the thickness, dip, and spatial extent of the units. Figure 2 shows a longitudinal section map of bench 9 from trench LFG-006. In total, 18 geologic units were identified based on distinction in grain size, colour, composition, stratigraphic position and other physical properties. Several units were correlated between benches and downward through the series of five successively excavated trenches (McLemore et al., 2005). Samples collected from these trenches form the basis for this research. All tests that are described here were performed on splits of original samples, so that test results can be compared between different methods.

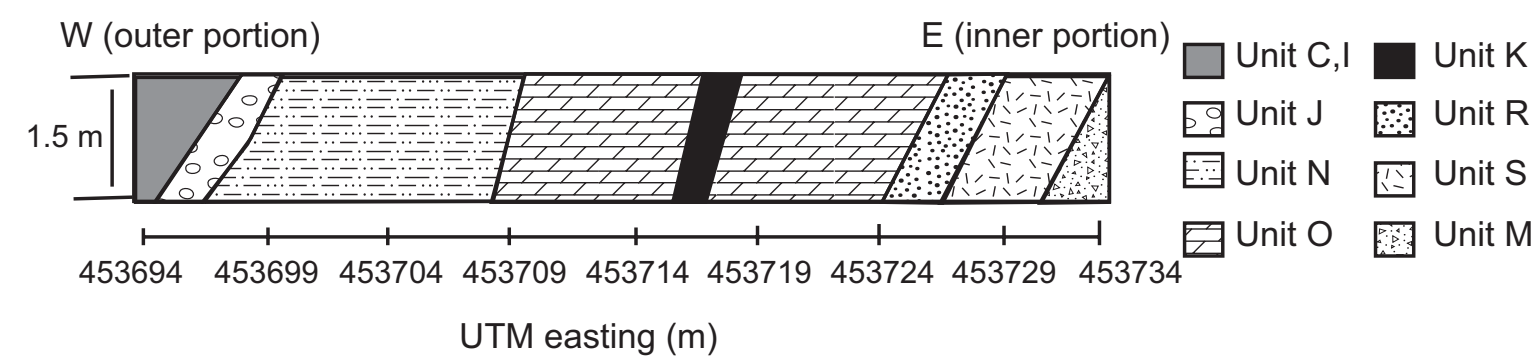

Figure 2 Geologic cross section of bench 9, trench LFG-006. Note that not all 18 geologic units are present in this bench. Note the vertical exaggeration; actual dips of strata were $\mathbf{2 0 - 4 0}{ }^{\circ}$

\subsubsection{Index properties and mineralogy}

In order to comprehend the contribution of weathering to the long-term stability of the GHN rock pile, the first approach was to collect and compile data from physical, mineralogical, and chemical characterisation of the rock pile material. The procedure followed was to test the geotechnical and geomechanical characteristics of samples across a range of weathering states that were defined by petrology, mineralogy, and chemistry. Mineralogy of the samples was determined using a modal mineralogy analysis. The modal mineralogy combines results from various chemical and mineralogical analyses, including petrography, clay mineralogy, pyrite concentrations using the Rietveld method, and whole rock chemistry from X-ray fluorescence (XRF) spectrometry (McLemore et al., 2006a, 2006b). Petrographic analyses were performed using a binocular microscope with additional microprobe and X-ray diffraction analyses. Clay mineralogy of major clay minerals groups was performed using standard clay separation techniques and X-ray diffraction analyses. Weathered samples show a change in colour, loss or obscuring of original igneous texture within many rock fragment grains, and increase in weathered minerals (i.e. gypsum, jarosite; Campbell and Lueth, in press).

Numerous weathering indices were evaluated in this research. A weathering index is a measure of how much the sample has weathered. Most of the weathering indices in the literature are based only on geochemical parameters, which restrict their application to the type of environment for which they were developed. A simple weathering index (SWI) was developed to differentiate the weathering intensity of Questa rock pile materials (SWI=1, fresh to $\mathrm{SWI}=5$, most weathered; Viterbo et al., in review). The SWI accounts for changes in colour, texture, and mineralogy due to weathering, but it is based on field descriptions. In addition, the Weathering Potential Index, WPI (Reiche, 1943; Infran, 1996, 1999) and the Miura index, MI (Miura, 1973) show a positive correlation with paste $\mathrm{pH}$ (Figure 3). Paste $\mathrm{pH}$ is another indication of weathering used in this project, but it too has limitations. Paste $\mathrm{pH}$ is the $\mathrm{pH}$ measured on a paste or slurry that forms upon mixing soil material and deionised water. In an acidic material, paste $\mathrm{pH}$ is an approximate measurement of the acidity of a soil material that is produced by the oxidation of pyrite and other sulfides. A low paste $\mathrm{pH}(2-3)$ along with yellow to orange color and the presence of jarosite, gypsum, and low abundance to absence of calcite is consistent with oxidised conditions in the Questa rock piles (McLemore et al., 2006a, b). The paste $\mathrm{pH}$ and the weathering indices show a general trend of increasing weathering from the less oxidised inner portion to the more oxidised outer portion (Figure 4; McLemore et al., 2006b). These weathering indices reflect changes in mineralogy (i.e. calcite-pyrite to gypsum-jarosite and dissolution of silicate minerals during weathering).

Physical properties characterised in this study included field moisture, and wet and dry densities (using a nuclear gauge device). In the laboratory, splits of original sample material were used for measurements of moisture content, grain size, Atterberg limits, and specific gravity, according to ASTM standard procedures 
(ASTM, 2001a,b, 2002a,b). Also, direct shear measurements were conducted on soil matrix samples, while point load strength and slake durability tests were performed on rock fragments based on these sample splits.
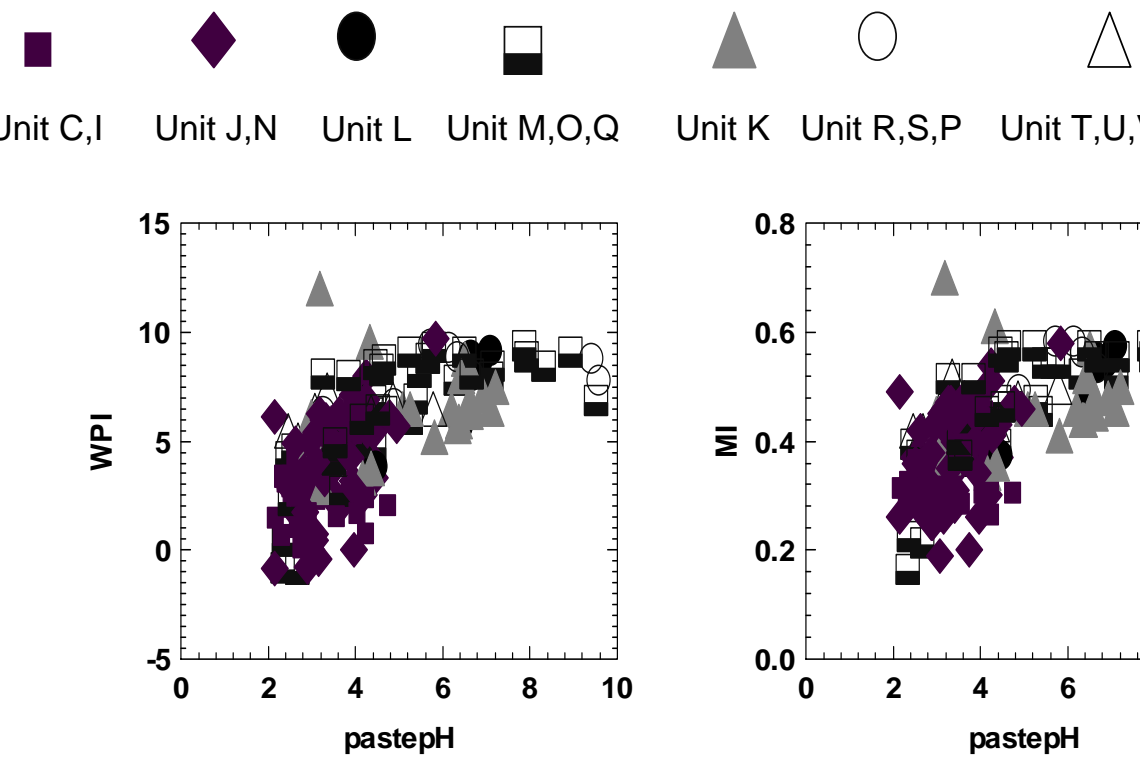

\section{Unit $\mathrm{K} \quad$ Unit R,S,P Unit T,U,V,W}

Figure 3 Scatter plots of WPI and MI versus paste pH for all GHN samples
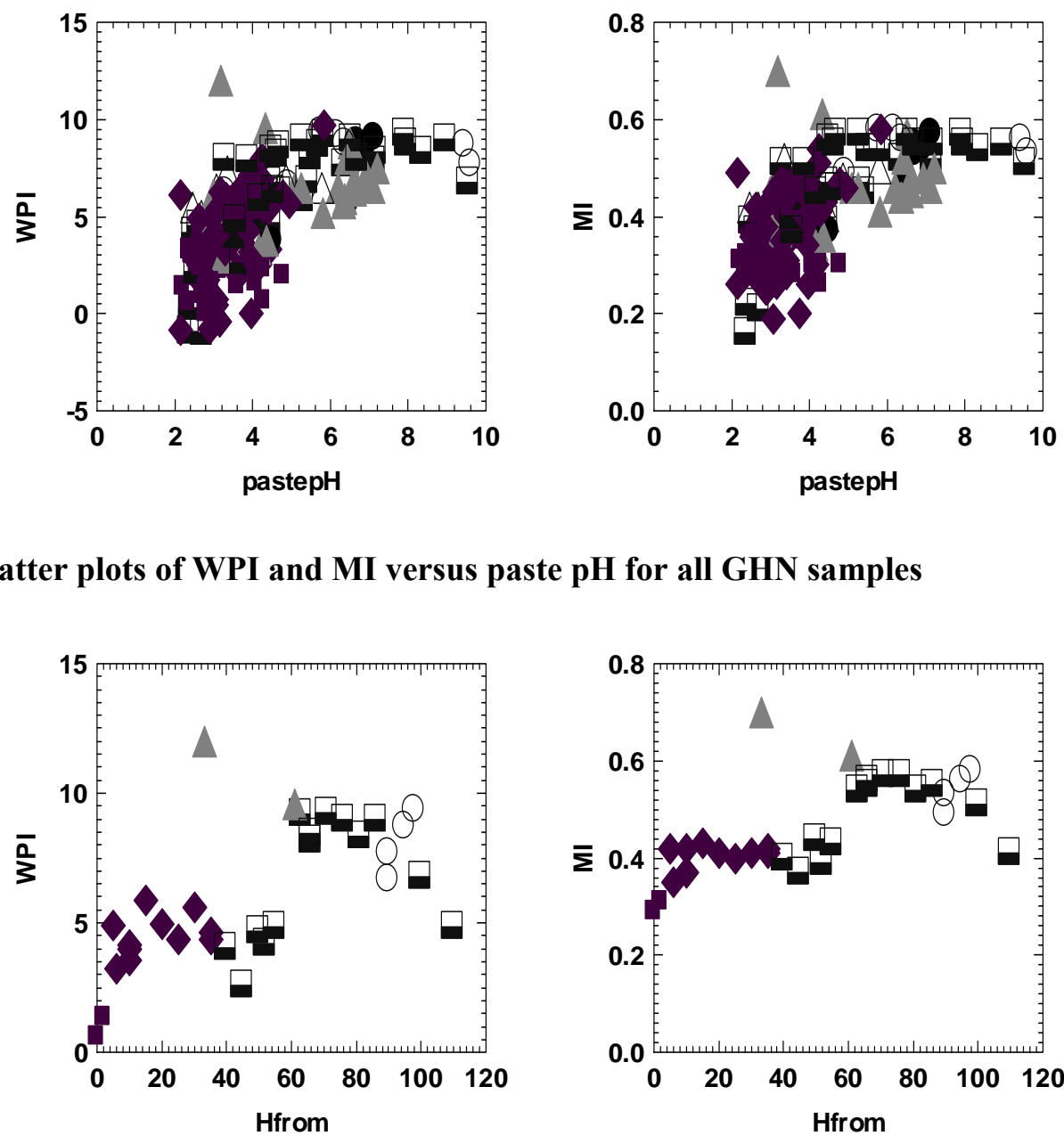

Figure 4 Scatter plots of the WPI and MI weathering indices with distance across bench 9, trench LFG-006. The outer oxidised edge is at Hfrom $=0 \mathrm{~m}$ and the inner zone of the bench is at Hfrom $=105 \mathrm{~m}$. Weathering increases towards the left. See Figure 3 for legend

\subsection{Direct shear tests}

The shear strength of granular soil is frequently characterised by its internal friction angle $(\phi)$. The internal friction angle for granular materials is a function of the following characteristics (Hawley, 2001; Holtz and Kovacs, 2003):

- Particle size: friction angle increases or decreases with increase in particle size.

- Grain quality: weak rock such as shale versus strong rock such as granite.

- Particle shape and roughness of grain surface: friction angle increases with increasing angularity and surface roughness.

- Grain size distribution: well graded soil has a higher friction angle than a poorly graded soil. 
- State of compaction or packing: friction angle increases with increasing density (decreasing void ratio).

The determination of the internal friction angle $(\phi)$ and cohesion (c) is commonly accomplished by direct shear test or triaxial tests. The direct shear test was preferred because of its simplicity, reliability and lower cost. It has been found that soil parameters $\phi$ and $\mathrm{c}$ obtained by direct shear testing are nearly as reliable as triaxial values. Limitations of the direct shear test were recognised and taken in consideration to minimise its effects in the results. One of the limitations identified was the inability to control or monitor pore water pressures during the direct shear test. Air drying the samples before being tested was adequate to reduce the chance of pore water pressure build up during the experiment.

Direct shear tests were performed in a $50.8 \mathrm{~mm}$ shear box, using manual operation. Samples were first sieved on a No. 6 sieve $(3.35 \mathrm{~mm})$, then a minimum of four fractions of approximately $120 \mathrm{~g}$ of each specimen were used for the tests. A dry density of $1.7 \pm 0.2 \mathrm{~g} / \mathrm{cm}^{3}$ was achieved for all samples. This density was based on the nuclear gauge field measurements, for which the dry density ranged from 1.06 to $2.31 \mathrm{~g} / \mathrm{cm}^{3}$ with an average of $1.69 \mathrm{~g} / \mathrm{cm}^{3}$ and standard deviation of $0.15 \mathrm{~g} / \mathrm{cm}^{3}$. A small density range was desired to reduce the number of variables affecting the friction angle. All specimens were prepared by lightly compacting three lifts to attain the same relative compression. Each lift was carefully placed by pouring the soil with a spoon in order to minimise segregation. A displacement rate of $0.5 \mathrm{~mm} / \mathrm{min}$ and normal stress varying from 159 to $800 \mathrm{kPa}$ were adopted for all the tests. For dry samples used in the experiments, the shear rate is not important since no pore water is present. Normal stresses required for testing were estimated by dividing the applied load by the area of the shear box. Loads represented the weight of the rock pile overburden consistent with the depth of the sample in the rock pile. Using a $50.8 \mathrm{~mm}$ shear box, the normal stress varied between 50 and $800 \mathrm{kPa}$. These values duplicate depths in the rock pile between 3 and $48 \mathrm{~m}$ (considering sample density of $1.69 \mathrm{~g} / \mathrm{cm}^{3}$ ).

Peak shear stress and residual shear stress were determined from plots of shear stress versus normalised displacement (Figure 5 left). All tests were continued until the shear stress became constant or until a maximum shear deformation of $10 \mathrm{~mm}$ had been reached, per ASTM D3080 recommendation (ASTM, 1998). In almost all samples the maximum shear stress was achieved at deformation less than $10 \mathrm{~mm}$. Internal friction angle was obtained using a linear best-fit line from the plot of peak shear strength versus normal stress (Figure 5 right). The residual friction angle was obtained using a similar best-fit line.
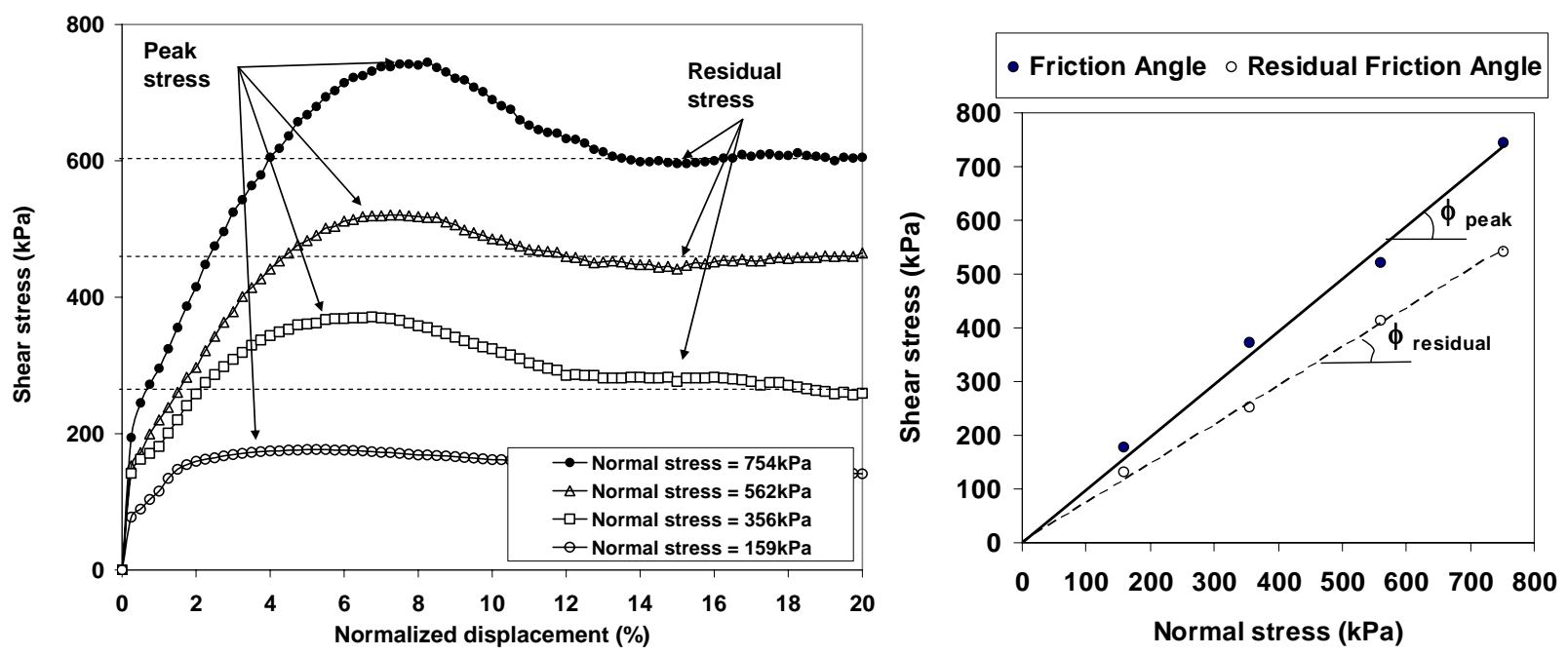

Figure 5 Left: Example of a shear stress versus shear displacement plot for sample GHN-JRM-0037. Right: Example of a Mohr-Coulomb diagram showing the best fit line for the peak internal friction angle and the residual internal friction angle 


\subsubsection{Verification of direct shear test results}

In order to verify the accuracy of the adopted procedure, some samples were tested in duplicate or triplicate. In addition, tests were conducted using a calibrated ELE direct shear testing apparatus at Kleinfelder Laboratory in Albuquerque, NM. The proving ring for this motorised apparatus is annually calibrated. The purpose of these tests was to provide validation of the tests conducted with the manual Soiltest shear box machine in the New Mexico Tech (NMT) Mineral Engineering Department. The Mohr-Coulomb diagrams for samples GHN-KMD-0014 and GNH-KMD-0017 tested using both machines are shown in Figure 6. The shear test results using the ELE machine fell along the trend lines defined by data generated with the machine at NMT. The addition of the corroborating data did not change the $\phi$ values. Therefore, all test results obtained at NMT are considered to be representative and reproducible.
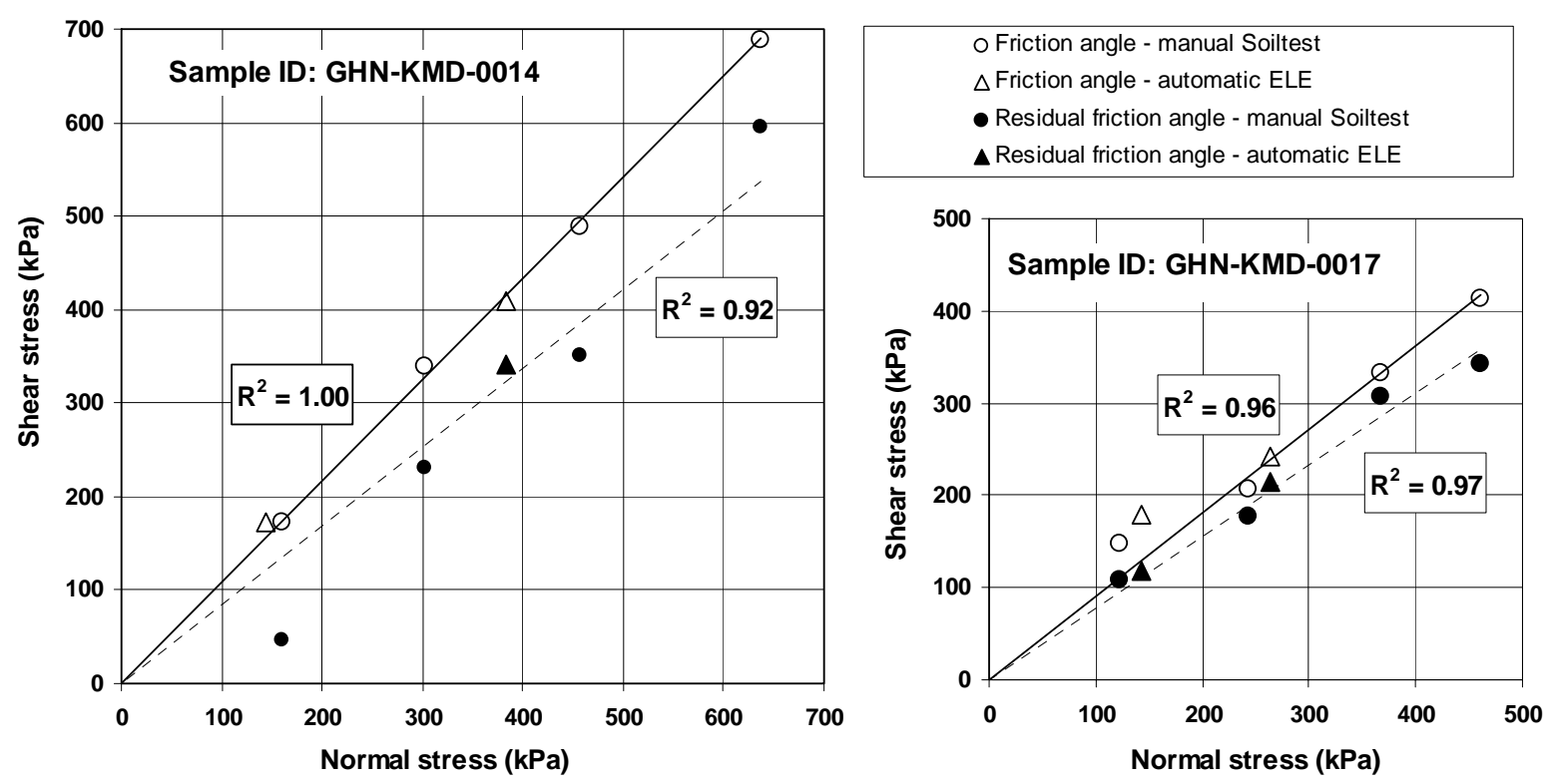

Figure 6 Mohr-Coulomb diagrams for two distinct samples using data points generated by both the automatic ELE and the manual Soiltest shear box equipment

\subsection{Slake durability tests}

The slake durability test was developed by Franklin and Chandra (1972) and recommended by the International Society for Rock Mechanics (ISRM, 1979) and standardised by the American Society for Testing and Materials (ASTM, 2001). The purpose of the test is to evaluate the influence of alteration on rocks by measuring their resistance to deterioration and breakdown when subjected to simulated wetting and drying cycles. The durability of rocks can be described as their resistance to breakdown under weathering conditions over time. Slaking is defined as the swelling of rocks containing clay minerals when in contact with water (Franklin and Chandra, 1972). The slake durability index $\left(\mathrm{ID}_{2}\right)$ is a measure of durability and provides quantitative information on the mechanical behaviour of rocks according to the amount of clay and other secondary minerals produced in them due to exposure to climatic conditions (Fookes et al., 1971).

The test consists of a representative sample containing 10 rock pieces, each weighing between 40 and $60 \mathrm{~g}$, with a total sample weight ranging from 450 to $550 \mathrm{~g}$. The sample is placed in a screen drum and ovendried at a temperature of $110 \pm 5^{\circ} \mathrm{C}$. After the sample is cooled to room temperature, the drum is immersed in distilled water and rotated at a speed of $20 \mathrm{rpm}$ for $10 \mathrm{~min}$. The sample is then oven-dried to a constant weight. The sample is submitted to 2 such cycles of wetting and drying. The $\mathrm{ID}_{2}$ is obtained from: 
Table 1 Slake durability index

classification (Franklin

and Chandra, 1972)

\begin{tabular}{ll}
\hline $\mathbf{I D}_{\mathbf{2}} \mathbf{( \% )}$ & Durability classification \\
\hline $0-25$ & Very low \\
$26-50$ & Low \\
$51-75$ & Medium \\
$76-90$ & High \\
$91-95$ & Very high \\
$96-100$ & Extremely high \\
\hline
\end{tabular}

Table 2 Point load strength index classification (Broch and Franklin, 1972)

\begin{tabular}{ll}
\hline Is50 (MPa) & Strength classification \\
\hline$<0.03$ & Extremely low \\
$0.03-0.1$ & Very low \\
$0.1-0.3$ & Low \\
$0.3-1.0$ & Medium \\
$1.0-3.0$ & High \\
$3.0-10$ & Very high \\
$>10$ & Extremely high \\
\hline
\end{tabular}

$$
I D_{2}=\frac{W_{A}-W_{D}}{W_{B}-W_{D}} \times 100
$$

where $\mathrm{W}_{\mathrm{B}}$ is the mass of drum plus oven-dried sample before the first cycle, $\mathrm{W}_{\mathrm{A}}$ is the mass of drum plus oven-dried sample retained after the second cycle, and $\mathrm{W}_{\mathrm{D}}$ is the mass of drum.

All samples were visually described and classified according to the $\mathrm{ID}_{2}$ values range after the second cycle of the slake durability test. Categories for visual description include (Franklin and Chandra, 1972): Type I, where pieces remain virtually unchanged, Type II, where the sample consists of large and small pieces and Type III with exclusively small fragments. Classification based on $\mathrm{ID}_{2}$ values is presented in Table 1 .

\subsection{Point load tests}

The point load test is a simple test for estimating rock strength. The equipment is comprised of a loading frame that measures the force required to split the sample and a system for measuring the distance between the two contact loading points. The point load test can be performed on samples with different shapes, both cylindrical (core) and irregular shaped (Broch and Franklin, 1972).

The point load strength index (Is50) corresponding to a specimen of $0.05 \mathrm{~m}$ in diameter, given in $\mathrm{MPa}$, is calculated using (ISRM, 1985):

$$
\text { Is50 }=\frac{P}{D_{e}^{2}} \times F
$$

where $P$ is the peak load, $D_{e}$ is the equivalent core diameter, and $\mathrm{F}$ is a size correction factor $\left(\mathrm{D}_{\mathrm{e}} / 0.050\right)^{0.45}$. All samples are classified according to the classification index in Table 2.

\section{$4 \quad$ Results}

\subsection{Index properties and mineralogy}

Moisture content and specific gravity results of matrix soil ranged from 2.8 to $17.3 \%$ and 2.60 to 2.84 , respectively. Most of the samples from the GHN rock pile are classified as poorly graded gravels with fines and sand according to the United Soil Classification System (Gutierrez, 2006). Most of the fines were identified as inorganic clay with low swell potential (CL-group); the remaining samples fall in the ML category, which is inorganic silt (Gutierrez, 2006). Clay mineralogical analyses from unweathered drill core samples and from the GHN rock pile showed similar results, suggesting that the majority of clay minerals in the GHN samples were derived from the original, pre-mined hydrothermal alteration and not post-mining weathering (McLemore et al., 2006b; Donahue et al., 2007). The physical breakdown of the rock during the blasting, excavation process and deposition into the rock piles most likely released clay minerals contained within the phenocrysts and groundmass.

\subsection{Direct shear tests}

Direct shear test results are given in Table 3. The peak internal friction angle and residual friction angle ranged from 42 to $47^{\circ}$ and from 37 and $41^{\circ}$, respectively. Grain shape and texture were assessed by petrographic methods and electron microprobe, and involved examination of the grain shape and texture of 
the finer-grained soil component of the samples, as well as of the rock fragments within the rock pile material. The classification of the shapes of clasts was based on the AGI data sheet 18.1 comparison chart for estimating roundness and sphericity (Figure 7A). Based on this classification, sphericity ranged from subprismoidal to subdiscoidal and roundness ranged from very angular to subrounded (McLemore et al., 2006b). The high values of internal friction angle were in part attributed to grain shape. It was observed that most of the grains in the samples tested were predominantly angular to subangular (Figure 7B). Typical literature values of internal friction angle and residual friction angle for unweathered sand-sized material are 28 to $60^{\circ}$ (Holtz and Kovacs, 2003) and 26 to $35^{\circ}$ (Das, 1983), respectively. The lower range applies to round, loose sand and the higher range is for angular, dense sand.

Plots of weathering indices versus internal friction angle for samples from bench 9, trench LFG-006 show a trend of decreasing friction angle with increasing degree of weathering Figure 8. However, plots of all of the GHN data are not as clear. The effects of weathering are not linear because weathering is complex and dependent on lithology, composition of original rock, and composition of fluids interacting with the rock pile material. Although many studies in the literature presents similar results and indicates a reduction of strength with increasing weathering (e.g. Pasamehmetoglu et al. 1981, Seedsman and Emerson, 1985, Irfan 1996, 1999; Filipowicz and Borys, 2005), it cannot be generalised that weathering will always decrease mine rock/soil strength. Chemical weathering can produce cements, such as hematite and gypsum, that will join grains together and that are not easily dissolved in water. According to Pernichele and Kahle (1971) field studies of rock piles indicate that the cementing action of iron precipitates formed within the piles as a result of natural or production leaching tends to improve the strength of the piles over time. Generally, the cementation is so complete that vertical cuts are capable of standing for years without signs of failure. Furthermore, most of the literature studies indicated that clays were formed during weathering. However, work at Questa indicates that few, if any clays are actually formed in the rock piles by weathering (Donahue et al., 2006) or even in adjacent older, alteration scars, which are potential weathered analogues to the Questa rock piles (Luddington et al., 2005). The chemical conditions present during weathering at Questa are not conducive to forming clays.

Table 3 Summary of direct shear test results of samples from GHN, indexed by geologic unit

\begin{tabular}{|c|c|c|c|c|c|c|c|}
\hline \multirow{2}{*}{$\begin{array}{l}\text { Geologic } \\
\text { unit }\end{array}$} & \multicolumn{3}{|c|}{ Internal friction angle (degrees) } & \multicolumn{3}{|c|}{ Residual friction angle (degrees) } & \multirow{2}{*}{$\begin{array}{l}\text { Number } \\
\text { of samples }\end{array}$} \\
\hline & Avg. & Max. & Min. & Avg. & Max. & Min. & \\
\hline \multicolumn{8}{|c|}{ Oxidised, outer zone } \\
\hline I & 43 & 43 & 42 & 38 & 38 & 38 & 2 \\
\hline $\mathrm{J}$ & 44 & 45 & 43 & 39 & 38 & 38 & 3 \\
\hline \multicolumn{8}{|c|}{ Intermediate zone } \\
\hline $\mathrm{N}$ & 44 & 44 & 44 & 38 & 39 & 37 & 2 \\
\hline \multicolumn{8}{|c|}{ Unoxidised, internal zone } \\
\hline K & 44 & 47 & 42 & 38 & 39 & 37 & 3 \\
\hline $\mathrm{O}$ & 44 & 47 & 42 & 38 & 41 & 37 & 13 \\
\hline M & 44 & - & - & 41 & - & - & 1 \\
\hline $\mathrm{R}$ & 44 & 45 & 43 & 40 & 40 & 39 & 2 \\
\hline $\mathrm{S}$ & 45 & - & - & 37 & - & - & 1 \\
\hline $\mathrm{P}$ & 46 & - & - & 37 & - & - & 1 \\
\hline $\mathrm{U}$ & 44 & 46 & 43 & 38 & 39 & 37 & 4 \\
\hline $\mathrm{V}$ & 46 & 47 & 44 & 40 & 40 & 39 & 2 \\
\hline
\end{tabular}



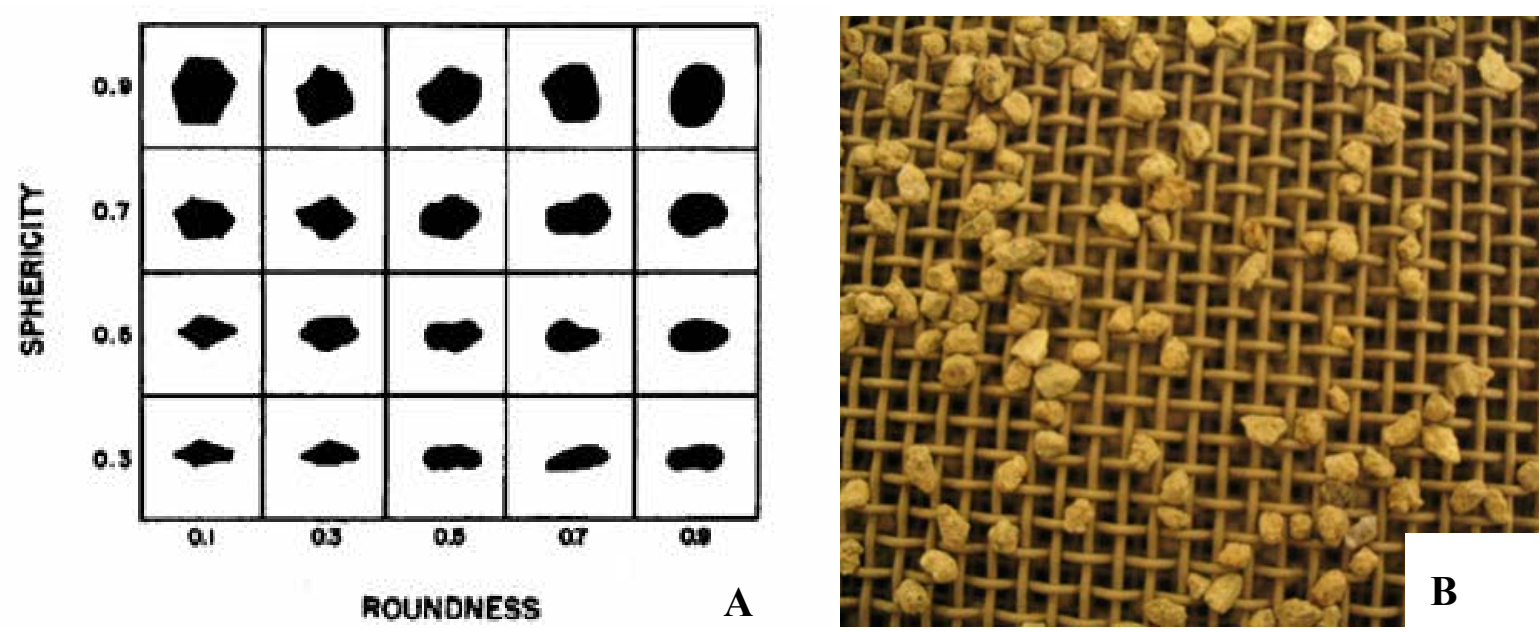

Figure 7 A) Typical roundness and sphericity chart. B) Close view of sample GHN-KMD-0072 grains. Note that majority of the grain are angular to subangular
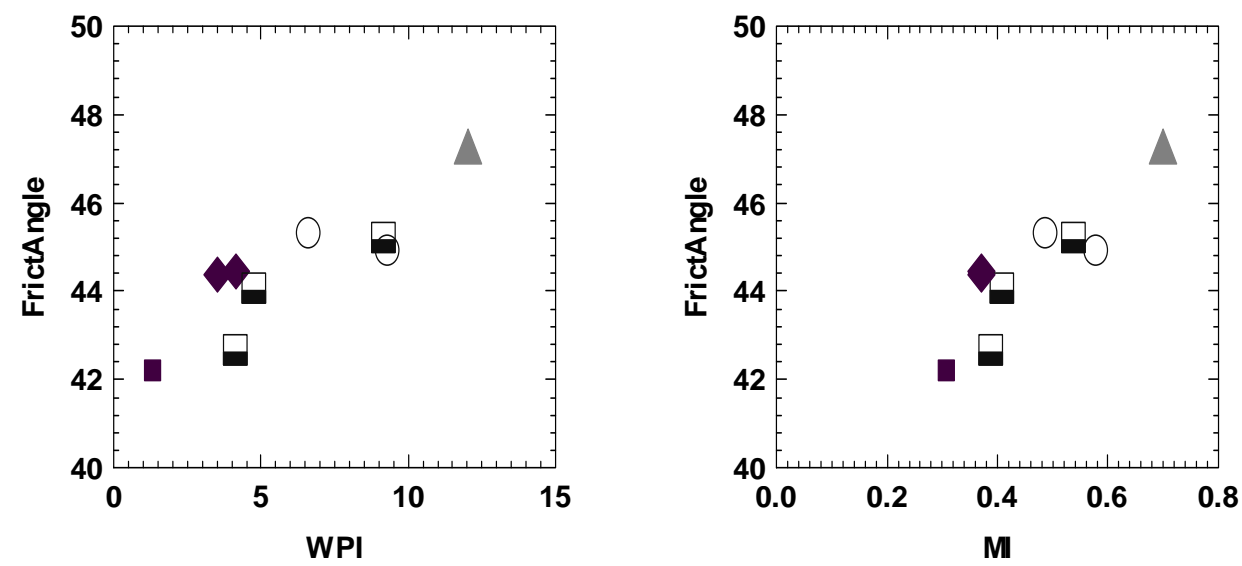

A
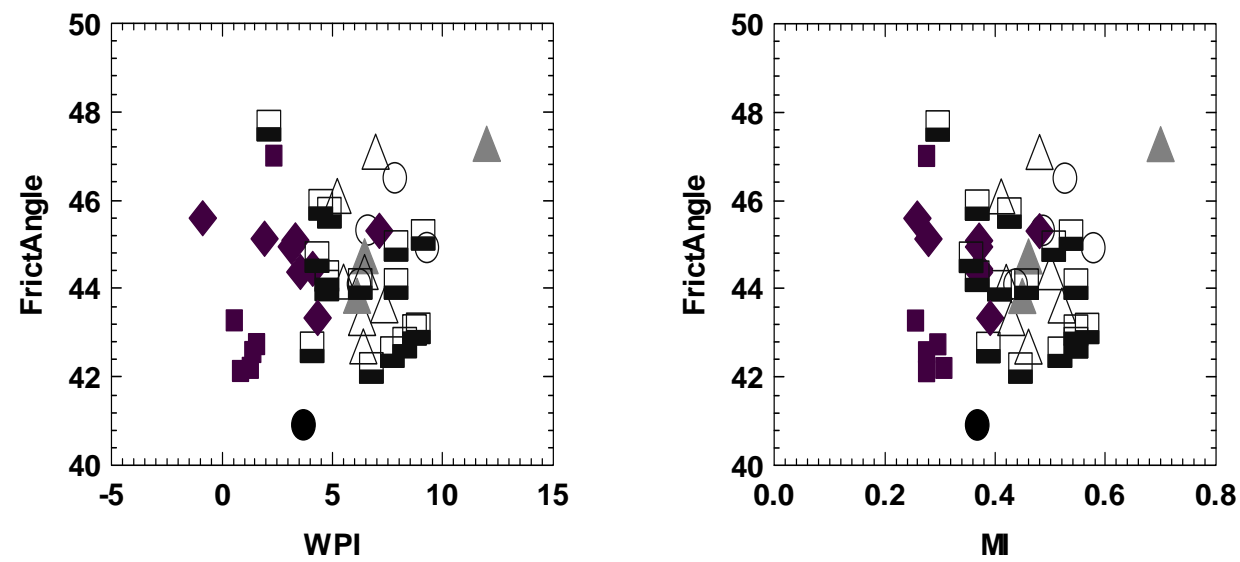

C

D

Figure 8 Scatter plot of internal friction angle versus A) weathering potential index (WPI) and B) Miura Index (MI) for samples from bench 9, trench LFG-006 and C) and D) all data from GHN. The weathering intensity increases as WPI and MI decrease 


\subsection{Slake durability and point load strength tests}

Slake durability tests and point load strength tests were performed on rock samples from GHN rock pile and core samples of the overburden, drilled before open-pit mining began.

\subsubsection{Drill core samples}

A total of 20 drill core samples were tested for slake durability and point load strength tests. The lithologies of the drill core samples tested are of andesite and rhyolite tuff (Amalia) similar to the rock fragments from GHN rock pile. The $\mathrm{ID}_{2}$ values for these samples range from 84 to $99 \%$, with all samples classified as having high to extremely high durability (Table 1). The Is50 values for these samples range from 1.3 to 6.9 MPa, with all samples classified with high and very high strength (Table 2). Tables 4 and 5 present summaries of the durability and strength classification for these samples.

Results show that lower slake durability index values correspond to samples of quartz-sericite-pyrite (QSP) altered rhyolite tuff and QSP-altered propylitised andesite. Some samples show a high degree of fracturing and contain gypsum in the fractures. These samples have low durability and strength. Therefore, durability and strength is highly affected by degree of fracturing. More details can be found in Viterbo (2007) and Viterbo et al. (in review).

\subsubsection{GHN rock pile samples}

A total of 90 samples from throughout GHN were tested for slake durability; point load strength tests were performed on a total of 31 samples. The averaged $\mathrm{ID}_{2}$ values ranged from 89 to $97 \%$, with all of the samples classified as having high to extremely high durability. These results indicate the degree of deterioration on these samples was not significant after two cycles. The averaged Is50 values ranged from 1.1 to $6.6 \mathrm{MPa}$. All samples were classified with medium to very high strength according to Broch and Franklin (1972). Table 5 presents a summary of the durability and visual descriptions, and Table 6 presents a summary of the strength classification for these samples.

The averaged $\mathrm{ID}_{2}$ and $\mathrm{Is} 50$ values for samples on the most oxidised portion of the pile, unit $\mathrm{I}$, are significantly lower than the averaged $\mathrm{ID}_{2}$ and Is50 values of samples on inner geologic units of the rock pile (Figure 9). Averaged $\mathrm{ID}_{2}$ and Is50 values for samples from the inner geologic units of the rock pile are very close to the averaged values of unweathered drill cores. Hence, samples on the interior of the pile have not been affected by or have not experienced significant amount of weathering.

Table 4 Summary of the slake durability classification durability and visual descriptions after two cycles. See section 3.3 for a description of the different visual classification units

Drill cores $(\mathbf{n}=\mathbf{2 0})$

GHN samples $(\mathrm{n}=90)$

\begin{tabular}{lcccc}
$\begin{array}{l}\text { Durability } \\
\text { classification }\end{array}$ & $\begin{array}{c}\text { Number and } \\
\text { \% of samples }\end{array}$ & Visual description & $\begin{array}{c}\text { Number and } \\
\text { \% of samples }\end{array}$ & Visual description \\
\hline High & $3(15 \%)$ & Type II & $5(5.6 \%)$ & Unit II \\
Very high & $5(25 \%)$ & Type II & $12(13.3 \%)$ & Type I (1), Type II (11) \\
Extremely high & $12(60 \%)$ & Type I (1), Type II (11) & $73(81.1 \%)$ & Type I (15), Type II (58) \\
\hline
\end{tabular}

Table 5 Summary of the strength classification for the drill core and GHN rock samples

\begin{tabular}{lll}
\hline & $\begin{array}{l}\text { Drill cores }(\mathbf{n}=\mathbf{2 0}) \\
\text { Strength classification }\end{array}$ & $\begin{array}{l}\text { GHN samples }(\mathbf{n}=\mathbf{3 1}) \\
\text { Number of samples }(\%)\end{array}$ \\
\hline Number of samples (\%) \\
\hline High & $0(0 \%)$ & $1(3.2 \%)$ \\
Very High & $8(40 \%)$ & $6(19.4 \%)$ \\
\hline
\end{tabular}



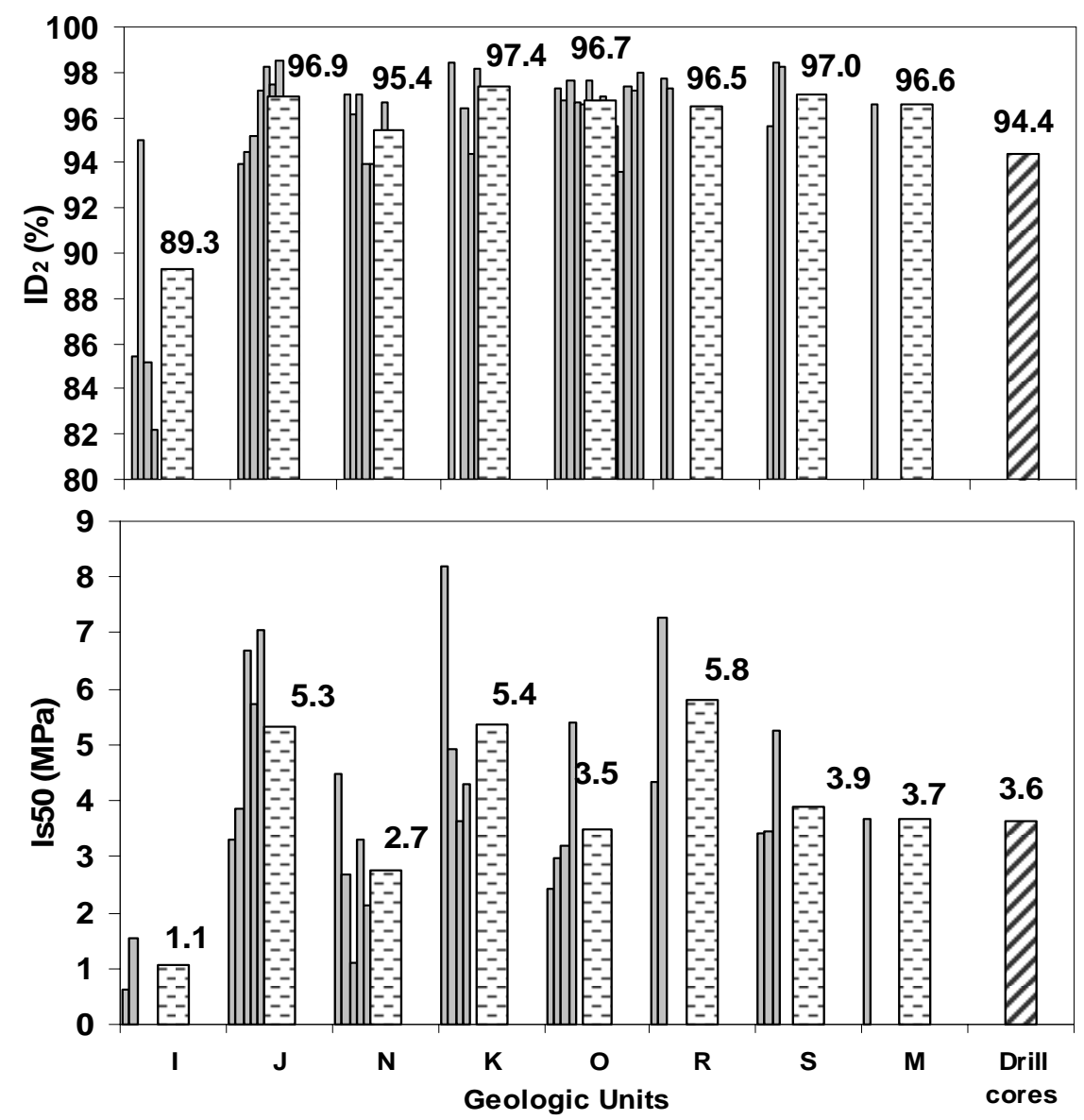

Figure 9 Bar graphs of A) slake durability index and B) point load strength index per geologic unit (Viterbo et al., in review). Grey and dashed bars indicate individual measurements and averages, respectively. The hatched bar represents the average of drill core measurements

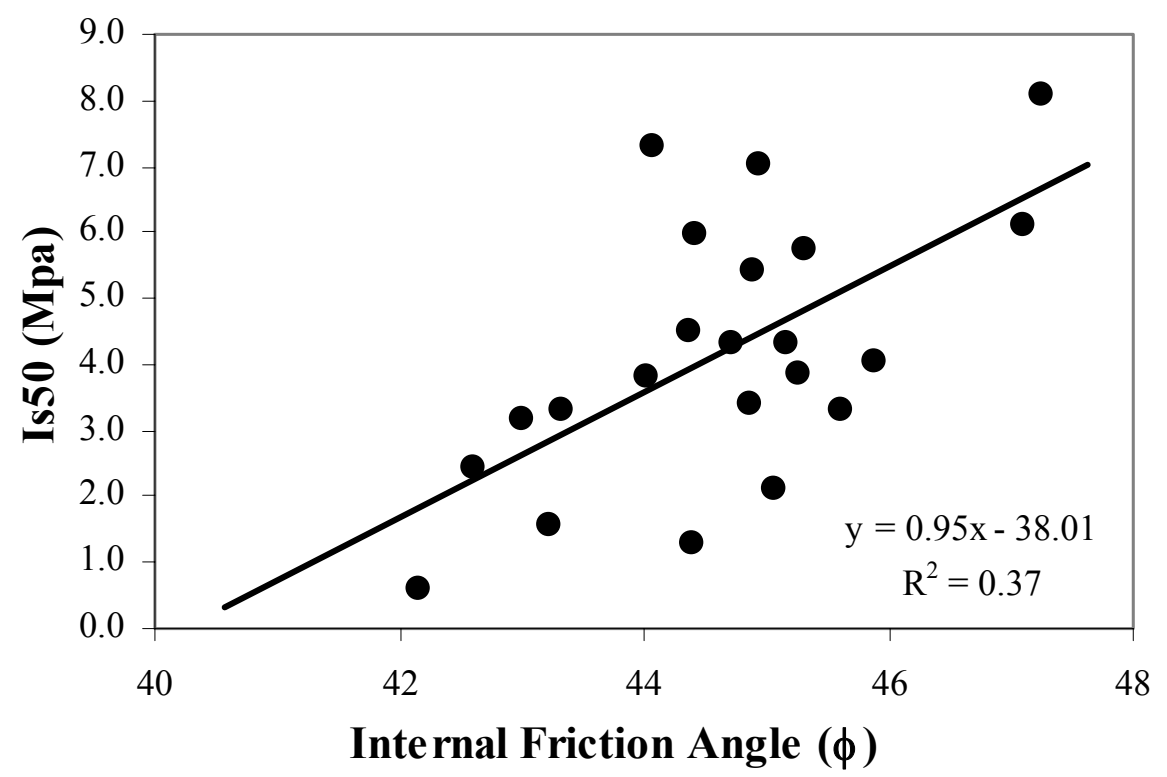

Figure 10 Scatter plot of Is50 of rock samples versus internal friction angle of soil samples 


\subsection{Geotechnical property comparison}

The lowest values for internal friction angles of soil samples and the lowest strength of rock specimens were observed in the most oxidised samples of Unit I (Figures 11 and 12). The degree of closeness between Is50 and internal friction given by the coefficient of correlation (r-value) of the regression line is 0.61 (Figure 10), which results in an $r^{2}$-value of 0.37 . This means that $37 \%$ of the variance on these properties can be explained by in-common factors. The $63 \%$ unexplained variance between these two engineering properties may be due to the nature of the specimens used for each test. Point load strength tests were carried out on rock fragments, while direct shear tests were carried out on specimens containing minus No.6 sieve particles.

A scatter plot between slake durability and point load for twenty of the same samples gives an $r^{2}$-value of 0.27 (Viterbo et al., in review), which is comparable to published results. Koncagül and Santi (1999) show a correlation coefficient of 0.4 for this relationship between slake durability and point load strength measurements. Their explanation for the data variability is based on properties of the rock masses they used.

\section{Conclusions}

The present study was carried out on rhyolite (Amalia Tuff) and andesite rock fragments and matrix soil samples from the GHN rock pile with the purpose of examining the effects of weathering on the geotechnical and geomechanical properties. These properties are very important for stability studies of rock piles. Direct shear tests of matrix soil sample splits resulted in internal friction angles $(\phi)$ and residual friction angles $(\phi$ residual) that ranged from $42^{\circ}$ to $47^{\circ}$ and from $37^{\circ}$ to $41^{\circ}$, respectively. These high values of $\phi$ were in part attributed to grain shape (subangular to very angular). The point load strength index values (Is50) for rock sample splits ranged from 1.1 to $6.6 \mathrm{MPa}$ with all samples classified as medium to very high strength. The slake durability index values $\left(\mathrm{ID}_{2}\right)$ measured for the same rock sample splits classified the material as having high to extremely high durability.

Friction angle, point load strength index and slake durability index of the GHN rock pile samples decreased as the degree of weathering increased in some samples but not all. However, the decreases were still quite small and suggest that 40 years of weathering have not substantially affected the shear strength properties of these rock pile materials. Some, but not all samples located on the outer edge of the rock pile disintegrated more and presented lower durability. Comparison of $\mathrm{ID}_{2}$ and Is50 values of fragments in the rock pile to values of un-weathered drill cores of rocks with similar lithologies to those in the pile shows that rock fragments in the GHN rock pile have not experienced considerable weathering after emplacement. Therefore, lower values of $\phi, \mathrm{ID}_{2}$, and Is50 of samples from the outer edge of the pile are likely due to post-deposition oxidation, which is consistent with the change in colour, loss or obscuring of original igneous texture on the edges and within many rock fragment grains, and increase in weathered minerals (i.e. gypsum, jarosite). Conversely, the $\mathrm{ID}_{2}$ and Is50 values of samples on the interior of the pile are similar to the values of unweathered drill core samples. Consequently, the samples from the interior of the GHN rock pile are not more weathered since its emplacement. In, general, GHN rock pile samples presented high durability and strength even after undergoing hydrothermal alteration, blasting, deposition, and exposure to weathering. Collectively, these results suggest that future weathering will not substantially decrease the friction angle of the rock piles with time. *

\section{Acknowledgements}

This project was funded by Chevron Mining Inc. (formerly Molycorp Inc.), and the New Mexico Bureau of Geology and Mineral Resources (NMBGMR), a division of New Mexico Institute of Mining and Technology (New Mexico Tech). We would like to thank the professional staff and students of the large multi-disciplinary field team for their assistance in the fieldwork and data analyses. We also would like to thank Jim Vaughn and Mike Ness of Chevron Mining Inc. for their training and assistance in this study. Remke van Dam, Ali Fakhimi, David Jacobs, and Dirk van Zyl reviewed an earlier version of this manuscript and their comments were appreciated.

*Because further study on the topic of this paper is in progress, interpretations and conclusions expressed in this paper are not necessarily those of Chevron Mining Inc. 


\section{References}

ASTM (1998) Standard test method for direct shear test of soils under consolidated drained conditions: D3080, American Society for Testing and Materials publication.

ASTM (2001a) Standard laboratory determination of water (moisture) content of soil, rock, and soil-aggregate mixtures: D2216, American Society for Testing and Materials publication, $482 \mathrm{p}$.

ASTM (2001b) Standard test method for liquid limit, plastic limit, and plasticity index of soils: D4318, American Society for Testing and Materials publication, $482 \mathrm{p}$.

ASTM (2001c) Standard Test Method for Slake Durability of Shales and Similar Weak Rocks: D464487 (Reapproved 1992), American Society for Testing Materials publication, $482 \mathrm{p}$.

ASTM (2002a) Standard test method for particle-size analysis of soils (D422), American Society for Testing and Materials publication.

ASTM (2002b) Standard test methods for specific gravity of soil solids by water pycnometer (D854), American Society for Testing and Materials publication.

Birkeland, P.W. (1999) Soils and geomorphology, Oxford University Press publication, 430 p.

Bowles, J.E. (1979) Physical and geotechnical properties of soils, McGraw-Hill publication, 478 p.

Broch, E. and Franklin, J.A. (1972) The Point Load Strength Test, International Journal of Rock Mechanics, Min. Sci., Vol. 9, pp. 669-697.

Campbell, A.R. and Lueth, V.W. (in press) Isotopic and Textural Discrimination Between Hypogene, Ancient Supergene, and Modern Sulfates at the Questa Mine, New Mexico: Applied Geochemistry.

Clark, M.J. and Samall, R.J. (1982) Slopes and weathering, Cambridge University Press publication, 112 p.

Das, B.M. (1983) Advanced soil mechanics, McGraw-Hill publication, 511 p.

Donahue, K., Dunbar, D. and McLemore, V.T. (2007) Origins of clay minerals in the Molycorp Goathill North rock pile, Questa, NM, SME preprint, 2007 annual meeting, 19 p.

Filipowicz, P. and Borys, M., 2005, Geotechnical properties of mining wastes and their utilization in civil engineering; in Proceedings of International Conference on Problematic Soils: May 25-27, 2005, Eastern Mediterranean University, Famagusta, N. Cyprus, pp. 259-267.

Franklin, J.A., Chandra, A. (1972) The Slake Durability Test, International Journal of Rock Mechanics and Mining Sciences, Vol. 9, pp. 325-341.

Fookes, P.G., Dearman, W.R. and Franklin, J.A. (1972) Some Engineering Aspects of Rock Weathering with Field Examples from Dartmoor and elsewhere, Q. J. Eng. Geol., Vol. 4, pp. 139-185.

Gerrard, A.J. (1988) Rocks and landforms, Academic Division of Unwin Hyman publication, 319 p.

Gutierrez, L.A.F. (2006) The influence of mineralogy, chemistry and physical engineering properties on shear strength parameters of the Goathill North rock pile material, Questa Molybdenum mine, New Mexico: M. S. thesis, New Mexico Institute of Mining and Technology, Socorro, 201 p., http://geoinfo.nmt.edu/staff/mclemore/Molycorppapers.htm, accessed December 06, 2007.

Hawley, P.M. (2001) Site selection, characterization, and assessment. in: W.A. Hustrulid. Slope Stability in Surface Mining. M.K. McCarter and D.J.A. Van Zyl (Ed), Society for Mining, Metallurgy, and Exploration,Inc., Littleton, pp. 267-274.

Holtz, R.D. and Kovacs, W.D. (2003) An introduction to geotechnical engineering, Pearson Education Taiwan publication, $733 \mathrm{p}$.

Irfan, T.Y. (1996) Mineralogy, Fabric Properties and Classification of Weathered Granites in Hong Kong, Quaternary Journal of Engineering Geology, Vol. 29, pp. 5-35.

Irfan, T.Y. (1999) Characterization of Weathered Volcanic Rocks in Hong Kong, Quaternary Journal of Engineering Geology, Vol. 32, pp. 317-348.

International Society for Rock Mechanics-ISRM (1979) Suggested methods for determination of the slake durability index, Int. J. Rock Mech. Min. Sci. Geomech.,Vol. 16, pp. 154-156.

Koncagül, E.C. and Santi, P.M. (1999) Predicting the Unconfined Compressive Strength of the Breathitt Shale Using Slake Durability, Shore Hardness and Rock Structural Properties, Int. J. Rock Mech. Min. Sci., Vol. 36, pp. 139-153.

Luddington, S., Plumlee, G., Caine, J., Bove, D., Holloway, J., and Livo, E. (2005) Questa baseline and pre-mining ground-water quality Investigation, 10. Geologic influences on ground and surface waters in the lower Red River watershed, New Mexico: U.S. Geological Survey, Scientific Investigations Report 2004-5245, 46 p.

McLemore, V.T., Lueth, V. and Walker, B.M. (2004) Alteration Scars in the Red River Vallley, Taos County, New Mexico. New Mexico Geological Society Guidebook, Vol. 55, pp. 19-24.

McLemore, V.T., Walsh, P., Donahue, K., Gutierrez, L., Tachie-Menson, S., Shannon, H.R. and Wilson, G.W. (2005) Preliminary status report on Molycorp Goathill North trenches, Questa, New Mexico, 2005 National Meeting of the American Society of Mining and Reclamation. American Society of Mining and Reclamation, Breckenridge, 26 p., http:/geoinfo.nmt.edu/staff/mclemore/Molycorppapers.htm, accessed December 06, 2007. 
McLemore, V.T., Donahue, K.M., Phillips, E., Dunbar, N., Walsh, P., Gutierrez, L.A.F., Tachie-Menson, S., Shannon, H.R., Luth, V.W., Campbell, A.R., Wilson, G.W. and Walker, B.M. (2006a) Characterization of Goathill North mine rock pile, Questa molybdenum mine, Questa, New Mexico. 7th International Conference of Acid Rock Drainage, American Society of Mining and Reclamation, Lexington, pp. 1219-1249.

McLemore, V.T., Donahue, K., Phillips, E., Dunbar, N., Smith, M., Tachie-Menson, S., Viterbo, V., Lueth, V.W., Campbell, A.R. and Walker, B.M. (2006b) Petrographic, mineralogical and chemical characterization of Goathill North mine rock Pile, Questa Molybdenum mine, Questa, New Mexico, 2006 Billings Land Reclamation Symposium, American Society of Mining and Reclamation, Lexington, CD-ROM, http://geoinfo.nmt.edu/staff/mclemore/Molycorppapers.htm, accessed December 06, 2007.

Meyer, J.W. and Leonardson, R.W. (1990) Tectonic, Hydrothermal and Geomorphic Controls on Alteration Scar Formation near Questa, New Mexico, New Mexico Geological Society Guidebook, Vol. 41, pp. 417-422.

Miura, K. (1973) Weathering in Plutonic Rocks (Part I)-Weathering During the Late-Pliocene of Gotsu Plutonic Rock, Journal Society Engineering Geology Japan, Vol. 14, No. 3.

Norwest Corporation (2003) Goathill North mine rock pile evaluation and conceptual mitigation plan. Unpublished Report to Molycorp Inc, $56 \mathrm{p}$.

Norwest Corporation (2004) Goathill North slide investigation, evaluation and mitigation report, Unpublished Report to Molycorp Inc, $94 \mathrm{p}$.

Pasamehmetoglu, A.G., Karpuz, C. and Irfan, T.Y., 1981, The weathering characteristics of Ankara andesites from the rock mechanics point of view; in Weak rock; soft, fractured and weathered rock: Proceedings of the international symposium on weak rock; v. I, A.A. Balkema, Rotterdam, Netherlands, p. 185-190 .

Pernichele, A.D. and Kahle, M.B. (1971) Stability of Waste Dumps at Kennecott's Bingham Canyon Mine. Tansactions, Society of Mining Engineers, AIME, Vol. 250, pp. 363-367.

Reiche, P. (1943) Graphic Representation of Chemical Weathering, Journal Sedimentary Petrology, Vol. 13, Society for Sedimentary Geology, pp. 58-68.

Seedsman, S.A. and Emerson, W.W. (1985) The Role of Clay-rich Rocks in Spoil Pile Failures at Goonyella Mine, Queensland, Australia. International Journal of Rock Mechanicas and Mining Science, Vol. 22, pp. 113-118.

Snedecor, G.W. and Cochran, W.G. (1967) Statistical methods, The Iowa State University Press publication, Ames, Iowa, $593 \mathrm{p}$.

Shaw, S.C., Wels, C., Roberston, A. and Lorinczi, G. (2002). Physical and geochemical characterization of mine rock piles at the Questa mine, New Mexico: An overview. 9th International Conference on Tailings and Mine Waste, Balkema, Rotterdam.

Tesarik, D.R. and McKibbin, R.W. (1999) Material properties affecting the stability of a 50-year-old rock dump in an active mine. U.S. Department of Health and Human Services, Pittsburgh Research Laboratory (ed), Pennsylvania, p. 2.

Uhle, R.J., Jr., 1986, A statistical analysis of rockfill data-Shear strength and deformation parameters with respect to particle size: M.S. thesis, Colorado State University, Fort Collins.

URS Corporation (2000) Interim mine rock pile erosion and stability evaluations, Questa mine. Unpublished Report to Molycorp Inc.

URS Corporation (2003) Mine rock pile erosion and stability evaluations, Questa mine, Unpublished Report to Molycorp, Inc.

Vallerga, B. A., Seed, H. B., Monismith, C. L., and Cooper, R. S. (1957) Effect of Shape Size and Surface Roughness of Aggregate Particles on the Strength of Granular Materials, Special Technical Publication No. 212, ASTM.

Viterbo, V.C. (2007) Effects of pre-miming hydrothermal alteration processes and post-mining weathering on rock engineering properties of Goathill North rock pile at Questa mine, Taos County, New Mexico: M. S. thesis, New Mexico Institute of Mining and Technology, Socorro, 274 p., http://geoinfo.nmt.edu/staff/mclemore/Molycorppapers.htm, accessed December 2007.

Viterbo, V.C., McLemore, V.T., Fakhimi A. and Sweeney, D. (in review) Effects of weathering on engineering properties of the Goathill North rock pile at the Questa mine, New Mexico: Engineering Geology.

Wilson, G.W., Fredlund, M.D. and Fredlund, D. (2005) The influence of shear strength properties on the stability of rock piles. Geological Society of America Abstract with programs, Vol. 37, No. 7, p. 395. 